\title{
Reflections of the Reproduced State Identity on Turkish Foreign Policy: Crises With the USA
}

\author{
Yeniden Üretilen Devlet Kimliğinin Türk Dış Politikasına \\ Yansımaları: ABD ile Krizler
}

\author{
Burak ERCOȘKUN \\ Öğr. Gör. Dr., İstanbul Yeni Yüzyıl Üniversitesi MYO, \\ Dıș Ticaret Bölümü, \\ burak.ercoskun@yeniyuzyil.edu.tr \\ https://orcid.org/0000-0003-1163-3906
}

\section{Araștırma \& Yayın Etiği \\ Bu makale en az iki hakem tarafindan incelenmiș, iThenticate yazılımı ile taranmış, araștırma yayın ve etiğine aykırılık tespit edilmemiștir.}

\section{BY-NC 4.0}

Bu makale Creative Commons Attribution-NonCommercial License altında lisanslanmıștır.

This paper is licensed under a Creative Commons Attribution-NonCommercial License

\section{Research \& Publication Ethics}

This article was reviewed by at least two referees, a similarity report was obtained using iThenticate, and compliance with research/publication ethics was confirmed.

\section{Copyright $\odot$}

Sakarya Üniversitesi, Sosyal Bilimler Enstitüsü, Sakarya/TÜRKIYE

Sakarya University, Institute of Social Science, Sakarya/TURKEY

\section{Atıf/Citation}

Ercoșkun, Burak. "Reflections of the Reproduced State Identity on Turkish Foreign Policy: Crises With the USA". Akademik Incelemeler Dergisi 16 / 2 (Ekim 2021): 249-269. https://doi.org/10.17550/akademikincelemeler.957726

Makale Türü/Article Type: Araştırma Makalesi/Research Article

Geliş Tarihi/Date Received: 25.06.2021

Kabul Tarihi/Date Accepted: 14.10.2021

Yayın Tarihi/Date Published: 15.10.2021

ISSN: $\quad 1306-7885$

E-ISSN: $2602-3016$

Cilt/Volume: 16 | Sayl/Issue: 2 |

Yll/Year: 2021 (Ekim/October) 


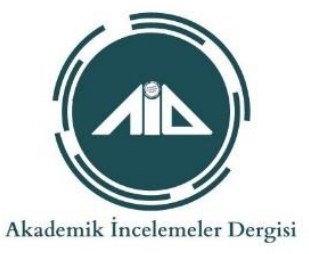

\title{
Reflections of the Reproduced State Identity on Turkish Foreign Policy: Crises with the USA
}

\begin{abstract}
Factors such as regional-international developments, political, economic, social conditions and security understanding separate the foreign policies of the states from each other and differentiate the expectations of the countries in mutual relations. Turkish-American relations, which have a history of nearly seventy years, have seen a fluctuating course with sometimes cooperation and sometimes crises. Therefore, identifying the root causes of crises that arise from different reasons and damage bilateral relations gains importance in terms of collaboration between the two countries. In this context, this study argues that the reproduction of Turkey's state identity in the changing international system after the Cold War caused crises in bilateral relations by differentiating foreign policy visions, threat perceptions and international goals with the United States. Based on this, the four crises, in the bilateral relations between Turkey and the United States, starting with the Syrian Civil War and continuing to the present day, will be examined in the dimensions of perception, discourse and politics. Then, possible policies are discussed through risks and opportunities to eliminate the tense atmosphere in Turkey-US relations. In the study, in addition to the literature review, the content and discourse analysis method is used methodologically by making use of the statements of policy makers.
\end{abstract}

Keywords: International Relationship, Turkey, USA, Political Crises, Alliance-Security Dilemma

\section{Yeniden Üretilen Devlet Kimliğinin Türk Dış Politikasına Yansımaları: ABD ile Krizler}

\section{Öz}

Bölgesel-uluslararası gelişmeler, siyasi, ekonomik, toplumsal koşullar ve güvenlik anlayışı gibi etkenler, devletlerin dış politikalarını birbirinden ayırmakta ve karşıllklı ilişkilerde ülkelerin beklentilerini farklılaștırmaktadır. Yaklaşık yetmiş yıllık bir geçmișe sahip Türk-Amerikan ilișkileri ele alındığında bazen iş birliğine gidildiği bazense krizlerin yaşandığı dalgalı bir seyir görülmektedir. Farklı sebeplerden kaynaklanan ve ikili ilişkilere zarar veren krizlerin temel nedenlerini tespit etmek, iki ülke arasındaki iş birliği açısından önem kazanmaktadır. Bu bağlamda çalışmada Soğuk Savaş sonrası değişen uluslararası sistemde Türkiye'nin devlet kimliğinin yeniden üretilmesinin, ABD ile dış politika vizyonlarını, tehdit algılamalarını ve uluslararası hedeflerini farklılaștırarak ikili ilişkilerde krizlere neden olduğu savunulmaktadır. Buradan hareketle, Türkiye-ABD ikili ilişkilerinde Suriye iç savaşı ile başlayıp etkisi günümüze kadar süregelen dört kriz, algı, söylem ve siyasa boyutlarıyla irdelenecektir. Ardından ise Türkiye-ABD ilişkilerinde gerilimli atmosferden kurtulmak için riskler ve firsatlar üzerinden olası politikalar tartışılacaktır. Metodolojik olarak içerik ve söylem analizi metodu kullanılan çalışmada literatür taramasına ilaveten politika yapıcıların demeçlerinden de yararlanılmaktadır.

Anahtar Kelimeler: Uluslararası İlişkiler, Türkiye, ABD, Siyasi Krizler, İttifak-Güvenlik İkilemi 


\section{Introduction}

It is possible to find similarities in the foreign policy objectives of the states, which are the primary actors of international politics. For example, developing strategies to maintain their assets, protect their interests in international relations, and take a more influential position are some of them. However, the foreign political processes of states, as well as their internal political processes, are different from each other. Each state has its own foreign policy reality. Indeed, no state is equally affected by the outside world that surrounds it. For this reason, to understand the foreign policy of a state, it is necessary to look at the internal structure and political development of that state (Rosenau, 1971, 108).

In today's world, increasing democratization and civilization tendencies, and globalization have eliminated the distinction between domestic and foreign policy and made it necessary to address the identity phenomenon. At this point, it can be said that foreign policy is the reflection of power, and identity is one of the sources of power. Therefore, when analyzing foreign policy, the attitudes and approaches to identity should be considered. As a matter of fact, Wendt (1992), one of the leading theorists of constructivism, emphasizes that actors first define their identity and then determine their national interests according to the identity they represent. In addition, Wendt (1992) argues that the structure of the system is not fixed; the anarchic structure is affected by the interaction between the actors, and therefore the identity patterns built by the actors will change depending on the conjuncture. Thus, the way identities perceive the outside world is changing.

Another point that needs to be addressed in the context of identity is the causality relationship. Because the social field is too complex to be explained by a single factor, therefore, it is necessary to consider the phenomenon of identity as one of many variables. Based on this, the study aims to analyze Turkey's relations with the United States of America (USA) in the context of "identity" and explain how the bilateral relations crises are constructed. The primary hypotheses have been determined as such: Reconstruction of the state identity of any secondary power in a unipolar international system causes crises in its bilateral relations with the superpower of the system as it changes its foreign policy vision, threat perceptions and international goals.

To test the established hypotheses, recent crises in the context of Turkish-American relations will be analyzed with the dimensions of perception, discourse, and politics. As a matter of fact, determining the causes of crises can prevent the emergence of new crises, and this function can be an important factor in the future of relations. In this direction, firstly the constructivism approach that explains the relationship between identity and foreign policy and constitutes the theoretical basis of the study will be mentioned. Then, by referring to the historical interaction of Turkish state identity with the outside world, we will try to understand the nature of Turkey-US bilateral relations. In the continuation, four crisis that began with the Syrian Civil War and led to tensions will be examined in general terms. Finally, possible policies for exiting the tense atmosphere will be discussed by evaluating risks and opportunities in the context of crises in terms of the future of relations.

\section{Theoretical Framework}

While the agent-structure debates continue among traditional theories trying to understand and explain the phenomenon of international relations, the changes that occurred in the structure of the international system after the Cold War laid the 
groundwork for the constructivist approach that identity is the basis of interests. This assumption is explained by the argument that "in order to know what a state wants in international relations; it must first know who it is". However, since the identity of the state is built by inter-subject structures, the effects caused by the internal structures of the state are ignored. Therefore, interests derive from identities, and behaviors derive from structures formed in relation to identities. However, it is explained how the state, as the agent, perceives these structures. As a result, identity can tell how the state (agent) perceives the structure (Flockhart, 2006, 94).

According to Wendt, just as the people who do society are individuals, the agents of the international system are the states. Hence, the focus of analysis is on identities and structures built through interaction in the interstate system. This means that identity is singular and is only formed by states before international interaction. However, it is criticized for Wendt to adopt a completely statist approach. According to Zehfuss (2001, $340-341$ ), it is problematic to concentrate solely on state identity because the concept of identity is constantly reconstructed and transformed.

On the other hand, Wendt $(1999,247)$, while affirming the existence of anarchy in the international arena, does not accept the view that it has only one meaning. According to Wendt, three alternative conceptions of the culture of anarchy are possible: the Hobbesian, Lockean, and Kantian cultures. Relations between states are defined through notions of hostility in Hobbesian culture, competition in Lockean culture, and friendship in Kantian culture. In Hobbesian culture, states are enemies who do not respect each other's right to exist as independent entities. The existence of wars and the emergence of unstable power balances in an anarchic structure where international rules are not developed to limit the use of violence are the structural features of this culture. Lockean culture, on the other hand, developed on the logic of competition between competitors. Wendt attributes the decline in the death rate of modern states to international cultural change. Accordingly, the emergence of sovereignty as an international institution transformed the power policy of the Hobbesian structure. The Kantian structure represents the transformation of identity and interest in the international system. Common interests are prioritized over national interests (Wendt, 1999, 265-305). As a result, friendship and hostility, a set of inter-subject meanings, the role structure of actors, as a socio-psychological and cultural style of relations, shape the approaches and behavior of states towards each other. Therefore, the change and transformation in Turkish-American relations in the post-Cold War period should be evaluated in this context.

\section{Turkey's State Identity and Relations With the USA}

The origins of modern identity in Turkey date back to the last period of the Ottoman Empire. Although different identity discourses (Ottomans, Islamism, Turkism) were developed against Russian expansionism and ethnic fragmentation during this period, nation-building was seen by the Turkish political elite and military bureaucracy as the only way to maintain national sovereignty. At the end of this process, a Turkish nation with a shared Muslim identity was formed based on secular foundations. However, this formula, which turned into a state ideology, brought along some problems. One of these is the identity conflict between conservative social actors who strongly opposed the radical secularism policies and the secularist elite. The other is the polarization between the nation-state and ethnic and religious groups that resist it. Therefore, competition and conflict between identity groups have shaped Turkey's foreign policy orientations (Kösebalaban, 2011, 31-32). 
Internal and external factors in the nation-building process brought the principles of status quo-ism and Westernism to the fore in Turkish Foreign Policy. Status quo-ism means protecting the existing borders, which the Republic of Turkey has acquired and dominates after the foundation years, not wanting to change borders, not pursuing an irredentism policy regarding foreign minorities, and maintaining regional-global balances. Westernism, on the other hand, means producing policies in this direction and positioning itself within the Western system due to the historical, ideological, social, and cultural influence of the West on Turkey (Oran, 2011). These principles have made their effects felt significantly starting from its foundation.

Based on this, when Turkish American relations are examined, it is seen that common interests and security concerns during the Cold War brought the two countries closer together. During this period, the bipolar world order has manifested itself between the USA and the USSR. The power struggle between these two countries took place mainly in Europe and the Middle East. Immediately after the Second World War, the USSR started its expansion policy. The USSR's demands from Turkey for the Straits and Kars and Ardahan provinces, as well as its ambitions for the Balkans and Iranian oil, led to the US adopting a foreign policy approach aimed at surrounding the USSR and protecting the world from the Soviet threat under (Sönmezoğlu, 2006). In this context, Turkey's geopolitical position has become important for the USA (Athanassopoulou, 2001). From Turkey's perspective, the "Western orientation" has become stronger and more pronounced as the Soviet threat, whose roots date back to the Ottoman period, continued under Stalin's leadership after the Second World War. In other words, security concerns and economic aids have gained importance for Turkey, which has been conducting a Western-oriented foreign policy in the context of modernization since the republic's establishment. Bilateral relations deepened with military institutionalization under the 1947 Truman Doctrine and the intense economic institutionalization that emerged with the 1948 Marshall Plan (Erhan - Sıvış, 2017, 89). In the period in question, the Turkish identity built the USSR as an immediate and open threat in foreign policy and the USA and NATO as a security complex. Uslu (2000, 17-21) summarizes the factors that make up the Turkey-USA alliance during the Cold War as follows: Turkey's search for security against the expansionist USSR, American economic aid, the need for a superpower in the polarized system according to the Aron paradigm, strategic reasons, similar official ideology (anti-communism), domestic political reasons and the risks of an unconnected foreign policy. On the other hand, it is seen that TurkeyUSA relations have an asymmetric alliance relationship. As a matter of fact, in the period in question, the USA showed Turkey its realistic face on issues such as the Cyprus problem, poppy production, and arms embargo. According to Bal (2006), these disputes forced Turkey to adopt a multidimensional foreign policy in the 1970s. For example, the Demirel government, which attaches importance to economic development, has tried to pursue a balanced, versatile, and dynamic foreign policy between the USA, the USSR, and the Arab world. In summary, it can be said that the Cold War climate shaped the security-based alliance between the two countries. In other words, the view of the Soviet Union as a close and clear threat, and the Western alliance and NATO as a security umbrella was made possible by Turkey's Western identity. In short, the Soviets were built as enemies and the West as friends.

The end of the Cold War has radically changed the material and intellectual context in which Turkish policymakers have been accustomed for forty years. Turkey has experienced difficulties in transitioning from the relative security it used to have to an 
uncanny order in which regional conflicts took place, and in this context, the reconstruction of the "Western" identity was considered necessary. In other words, with the end of the Cold War, which formed the basis for a realistic analysis in general, the role of identity and culture in Turkish foreign policy became clear. In this context, Turkey has started to focus on regional security and cooperation interests. As a result, perceptions of identity-based on determined interests emerged as Eurasianism, NeoOttomans and Islamism (Oran, 2011). In summary, the outlines of Turkish Foreign Policy in the post-Cold War period are as follows: Integration with the EU, the continuation of the alliance-strategic partnership with the US, strengthening relations with Central Asia and the Russian Federation, evaluating the developments in the Middle East based on Turkey's interests and resolving the Kurdish problem.

On the other hand, Uzgel $(2010,243-244)$ claims that Washington is actively supporting and encouraging Ankara to expand the scope of its foreign policy and become more active in the Balkans and Central Asia during this period. Örmeci (2020b) also states that the United States evaluates Turkey in two different contexts during this period. The first is Turkey, a strong military ally that will actively support the US and NATO. The second is Turkey, a model country with soft power elements that facilitate the transfer of Eastern energy resources to Europe and allow a more moderate interpretation of Islam. As a result, the geopolitical shifts and power struggle experienced in the global and regional dimensions after the dissolution of the USSR required the USA to reposition Turkey. So much so that the nature of bilateral relations in the 1990s was defined as "strategic alliance" or "strategic partner" by Turkish and American policymakers. In other words, when the two countries had common interests, Turkey was considered a "strategic partner" by the United States. Joint strategic initiatives carried out in the Eurasian region after the Cold War also continued the asymmetric alliance relationship without any problems. However, the fact that foreign policy strategies, which were shaped according to internal and external conditions, began to differ over time brought the two countries against each other from time to time and caused crises.

In Turkish-American relations, which reached the relative size of the alliance during the Cold War period and its continuation, severe crises began to occur since the 2000s, and bilateral relations reached the point of rupture. The Memorandum of March 1 and the Sulaymaniyah incident have shown that bilateral ties will not be devoid of tension. For Turkey, these developments have made the credibility of the US/NATO security guarantees controversial. Like the Armenian lobby, the influence of anti-Turkish lobbies on the US Congress is another factor that undermines the Turkey's security dependence on the US (Oran, 2011). On the other hand, the September 11 attacks during this period also led to a change in international balances. Making a distinction between "us" and "the other" with elements such as identity, culture, rule, norms, discourse, the US has tried to legitimize its policies towards Islamic civilization with discourses such as democracy, human rights, freedom, and liberal economy and to get support from the international public (Şahin, 2019, 73-74). In this period, the "win-win" approach and the principle of "zero problems with neighbors" were at the forefront in Turkish foreign policy under the leadership of Davutoğlu. In this context, Turkey, which initiated peace processes to reconcile with Armenia, Cyprus, and the Kurds, turned towards developing closer political and economic relations with the regional powers around it (Sözen, 2010). On the other hand, Altunışık (2009) states that in the post-Cold War period, Turkey was under the influence of different tendencies such as conservative constructivism of the AKP, pro-Western liberalism, social democratic constructivism and 
new traditionalism that strengthened the Sevres syndrome. As a result, in the post-Cold War period, Turkey's traditional Western identity has been integrated with its historical, socio-cultural, religious, and geographical identity to create a new identity for a multidimensional foreign policy.

Although the AKP government's effort to rebuild relations with a new common strategic vision, Barack Obama's call for a "model partnership", and the close relationship between Trump and Erdogan contributed positively to Turkey-US relations, crises could not be prevented. At this point, it is worth noting that there are different views on the root causes of crises. For example, according to Çalış (2010), Turkey's search for an independent foreign policy in response to the US's desire to design Turkey's domestic and foreign policy in line with its own interests with the habits of the Cold War period caused crises and prevented the normalization of relations. According to the other view advocated by authors such as Pipes (2009), Rubin (2016) and Lévy (2018), Turkey is in the position of a country with a more Islamic and pro-Russian orientation in recent years. Danforth (2021) also claims that Erdogan and his circle see the West as both hostile and in decline, and therefore Turkey has adopted the harsh use of force to block and surround regional states that want to advance their interests in an unstable world. As a result, Turkish-American relations have remained outside of the strategic or model partnership, especially at the point reached by the civil war in Syria. Even, Danforth (2021) states that the parties are beginning to see each other as a strategic threat rather than an ally.

\subsection{Syria Civil War and PYD/YPG Crisis}

The events that started in Tunisia in 2011 spread rapidly to other countries in the region and called the Arab Spring, turned into a civil war between regime forces, opposition forces and ISIS in Syria. The different approaches of the United States, the superpower of the system, and Turkey, a regional power, towards the situation in Syria have brought the two countries against each other. Here, it would be appropriate to indicate the transformations in recent US foreign policy by opening a separate parenthesis. It is known that the USA focused more on the Middle East after the September 11 attacks, adopted a preventive war policy in its foreign policy with the Bush Doctrine and made cross-border interventions by evaluating various countries and groups in the region as elements that threaten the stability of the region (US National Security Strategy, 2002). In addition to the economic effects of the global crisis in 2008, the increase in the cost of the invasion in Iraq and the increasing anti-US rhetoric prompted Obama to change the foreign policy strategies followed by his predecessor Bush. In this context, American foreign policy strategies were redefined according to the Obama Doctrine, which was formalized with the 2010 US National Security Strategy and shaped by the 2015 US National Security Strategy. Thus, the USA started to support its allies militarily and diplomatically, instead of being involved in matters that do not directly threaten its security (US National Security Strategy, 2015).

The US initially considered the crisis in Syria as a protest movement that developed within the framework of the Arab Spring and supported regime change. However, the opposition's failure to act as a united group and present themselves as a democratic actor brought the US withdraw its support from the Syrian opposition. This situation caused the USA and Turkey to have different views on foreign fighters and terrorism. Because, according to the USA, the reason for the security problem in the region is foreign fighters and radicalization, and it is these elements that need to be fought. According to Turkey, on the other hand, the problem of foreign fighters and 
radicalization in the region is a result of the Assad regime, and to ensure security and stability, a national unity government representing all the Syrian people should be established (Kanat, 2015, 343). As a result, while Turkey supported the FSA and Turkmens who opposed the Assad regime, the US changed its diplomatic stance and policies against Syria with the emergence of ISIS in 2014 and started to use the PYD/YPG as a proxy against ISIS by accepting it as a legitimate opposition movement (Kanat et al., 2017, 8-10). At this point, Barkey (2016) argues that the Obama administration has no choice but to support the PYD/YPG, as ISIS has emerged as a more important source of threat.

Turkish authorities announced that documents and evidence were presented to the US authorities that the PYD/YPG built autonomous cantons based on the "democratic autonomy" approach advocated by the terrorist organization PKK to strengthen the infrastructure of the regions it acquired in Syria (Temizer, 2016). In the report of Amnesty International, it was stated that the PYD/YPG committed war crimes, and following the decrease of the threat of ISIS, they carried out demographic engineering activities in the region by forcibly displacing local populations and expanded its area of influence (Kanat, 2017, 326). On the other hand, US officials stated that the support for the PYD/YPG is limited, temporary and tactical, citing the ISIS factor. The then US Defense Secretary Mattis announced that Washington was planning to take back weapons supplied to Kurdish militias in northern Syria after the ISIS threat (Reuters, 2017). According to Örmeci (2020a, 44), the fact that the PYD/YPG seemed to be fighting against ISIS together with America affected American public opinion, and this situation was perceived as a betrayal by the Turkish government and the public. Indeed, in an interview with Al Jazeera, President Erdogan said that despite their agreement, the promises were not kept, and that Obama had deceived him (Atılgan, 2017). Erdogan also blamed the United States for supporting terrorism in Syria (Reuters, 2016). Akbaş et al. $(2019,2242)$ states that the experience of the Gulf crisis with the US requires much more attention to the PYD/YPG threat in Syria. Because at that time, while the US was intervening in Iraq, Turkey actively took a side with the USA, but its expectations were not met, it was economically damaged by the sanctions imposed on Iraq and had to struggle with the terrorism problem for years due to the PKK structures in Northern Iraq. Therefore, regarding the issue of PYD/YPG, which is the main expectation of Turkey, the visit of the US Special Representative for the Fight against ISIS to Ayn alArab during the Obama period and receiving a plaque from the PYD/YPG spokesperson has led to the question of bilateral relations for Turkey.

The US side also has some criticisms against Turkey. For example, Nauert, a spokesman for the US State Department at the time, stated that Turkey is not fighting ISIS adequately (Todayonline, 2018). Erdogan (Sözcü, 2018) responded to the accusation levelled by the United States by saying: "There are no ISIS militants left to fight in Syria. The United States is still piling weapons into the region under the pretext of fighting ISIS". Another view is that Turkey, which has been fighting terrorism since the 1990s, has actively participated in the operations against ISIS, opened its bases and allowed the peshmerga affiliated to the Iraqi Kurdish Regional Government to cross into Syria through its territory (Erdağ, 2017, 331-332). Also, according to another view, targeting Turkish citizens in the transfer of foreign fighters, which is one of the indispensable policies of ISIS, and seeing Turkey as a route both increases the security risks and expands the scope of Turkey's fight against ISIS (Yeşiltaş et al., 2016, 8). 
Washington also sees Turkey's approach to the Kurdish problem as part of the problem. While Obama praised Erdogan for initiating peace talks with Kurdish separatists in early 2013, Turkey's changing attitude towards the Kurds caused Erdogan to be greeted coldly by Obama in March 2016 (Nissenbaum - Lee, 2016). According to Rhee $(2020,5)$, US officials think that Turkey aims to have locally elected councils in Syria controlled by the Turkish government. For this reason, there is concern that Turkey will expand its political activity in the region and play a role in shaping Syria after the war. On the other hand, it is believed that the AKP leadership has adopted a rhetoric of resistance, condemning the unilateralism of the USA and the double standards of the West. For example, Langan (2017) argues that Turkey presents itself as a humanitarian and altruistic force in contrast to the imperialist, neo-colonial, demonized West, as it hosts more than 3.5 million Syrian refugees and has been one of the top aid providers in the last decade. In the words of Çağaptay (2019), Turkey has also resorted to a two-way strategy to manipulate Washington, stating that Moscow is willing to do more than the United States on the PYD/YPG issue. Accordingly, it is noted that if the PYD/YPG is not officially listed as a terrorist organization by NATO, it threatens to veto NATO defense plans for Poland and the Baltic countries (Reuters, 2019b).

During the reign of Trump, who took over from Obama because of the US presidential election in 2016, problems with the Syrian issue continued, and no progress was made. At this point, Sloat (2018) states that both Obama and Trump administrations do not have a concrete Syria policy. As a matter of fact, the statements made by the Pentagon and the Ministries of Foreign Affairs and Defense regarding the PYD/YPG contradicted each other, and differences of opinion emerged between the US Central Forces Command (CENTCOM) and the US European Command (EUCOM). According to Kanat (2018, 292-293), the lack of a certain US policy towards Syria increases the weight of actors in the field, such as CENTCOM, in policy-shaping, which leads to a severe lack of coordination between the foreign policymakers of the two countries. Gülmez (2020), on the other hand, claims that Trump's approach to Turkey at the notification level is inconsistent. Indeed, announcing his decision to withdraw from Syria by praising Turkey's regional leadership in the fight against terrorism, Trump later sent tweets and letters to Erdogan threatening to destroy Turkey's economy if Turkey launched a military offensive against Syrian Kurdish forces (Reuters, 2019a). In another tweet also, he explained that he is a big fan of Erdogan and wants to improve US-Turkey economic relations (Deutsche Welle, 2019).

For Turkey, the main problem with the Syrian crisis stems from its concern for the future status of the Syrian Kurds. As the PYD/YPG is the PKK balancing organizations for Ankara, Turkey sees Kurdish autonomy or independence in Northern Syria as a direct security threat to its regime. Therefore, Ankara has evaluated Washington's policy as a violation of its own red lines and a challenge to its own security (Örmeci, 2020b). This point of view contradicting with the USA required Turkey to develop new political strategies in the Russia-Iran-China axis, to take the field to protect its own interests and ensure its national security. Ultimately, Turkey tried to ensure border security with operations such as the Euphrates Shield, Olive Branch and Peace Spring. Stanicek (2019) claimed that these operations were related to ISIS and pro-Kurdish terrorist attacks as well as the 2016 coup attempt and that the AKP regime started to reconsider its alliance with the West, as it did not help Turkey in its fight against the putschists. In summary, the different threat perceptions and world views prevented Turkey and the USA from developing a joint strategy regarding Syria. 


\subsection{July 15 Coup Attempt and the FETO Crisis}

Another event that created a crisis of trust between the two countries was the coup attempt witnessed by Turkey on July 15, 2016 which was repelled by the resistance of the society, political actors, media, and state institutions. The Turkish authorities declared that the Gülen movement was responsible for the coup attempt, and this structure was officially proclaimed as the Fethullahist Terrorist Organization (FETO) by the Turkish state. On the other hand, after this failed coup attempt, Turkish media and government officials accused the USA of being involved in the conspiracy (The Economist, 2016). At this point, it should be said that there are some reasons behind the accusations made. For example, Miş et al. (2016) stated that, regardless of the ideological differences in Turkey, even though the society and political representatives agree on the responsibility of the coup attempt, the attitudes and discourses adopted by the US officials have strengthened the perception among the Turkish public that the US may have a role behind the coup attempt. As a matter of fact, the first statement made by the US regarding the coup attempt was the then Foreign Minister John Kerry's call for peace and stability. After hours, a statement was made by the White House as "All parties in Turkey should support the democratically elected government of Turkey, show sobriety and avoid any kind of violence or bloodshed". Two days after the coup attempt, Kerry warned the Turkish government not to overdo it in retaliation against the coup plotters (Williams - Snow, 2017). In addition, as Presidential Spokesperson Kalın (2016) has stated, the ringleader of FETO, who is trying to gain economic power by organizing within the state and seizing political power illegitimately and illegally, has been living in Pennsylvania for many years. The statements of some US names also support this perception. For example, retired American Lieutenant Colonel Peters (2016) on the night of the coup attempt told Fox News that the coup attempt was a positive development to prevent Turkey from slipping into an Islamist dictatorship and that he supported the coup. Similarly, after the coup attempt, Votel from the US Central Command said that the Pentagon's closest allies in the Turkish army were imprisoned in Turkey (Paletta, 2016). On the other hand, there is a "Treaty of Mutual Legal Assistance in Extradition and Criminal Procedures" dated 1980 between Turkey and the USA. In addition, in the words of Akgün $(2016,6)$, although the documents proving Gülen's involvement in the crimes in Turkey were sent to the US, Turkey's request for extradition remained inconclusive, which strengthens the US's connection with the coup. Another view is that Gülen continues his anti-Turkey activities in the USA (Oktay, 2021).

On the other hand, the USA denies the accusations that it is related to the coup attempt. There are opinions that the evidence of US involvement in Turkish coups is generally based on legends in the media and that this situation is used for propaganda purposes to increase anti-Americanism. Therefore, it can be said that the general perception in the US about the coup attempt is exactly the opposite of that in Turkey. For example, according to Danforth (2021), the coup attempt was used by Erdogan for political gain. On the other hand, the methods of government after the coup attempt were also criticized. Democratic Party of the time, MP Meeks, arguing that many people who were not related to the coup were arrested and stated that there were human rights violations (Euronews, 2017). In addition, the failed coup attempt and subsequent purges within the Turkish security bureaucracy created a negative atmosphere in Washington regarding Turkey's military capabilities (Timoçin, 2017). Finally, it is emphasized by the US authorities that it is the US judiciary that will decide on the extradition of Gülen to Turkey (Mason - Landay, 2016). 
Another issue that caused tension between the two countries related to the FETO issue was the Pastor Brunson incident. Brunson, a long-time resident of Turkey, was declared by the Turkish judicial authorities to be connected to the July 15 coup attempt and sentenced to three years in prison on espionage charges (Örmeci, 2020a, 43). While this development was criticized in the American press, Trump demanded the release of Brunson in his statements. When these demands were unrequited, the US dollar started to appreciate against the Turkish lira in a short time, and this situation was associated with the USA by the Turkish authorities. In the ongoing process, Brunson was released in view of the period of detention. However, prior to this development, Trump made comments about Brunson on social media against Turkey. Özel states that the Brunson case is symbolic and that the problems between Ankara and Washington stem from the strategic disputes between the two countries regarding the projections of the Middle East and the future of the Kurds (as cited in Özel, Aktan, 2018). Turaman and Çelik $(2018,130)$ also state that political, logistical and ammunition support to FETO continued in the Trump period, as was the case with the PYD/YPG. As a result, it should be said that these two structures, which are on the list of terrorist organizations in Turkey, are not evaluated by the United States in this context.

\subsection{S-400 Air Defense Systems and CAATSA Sanctions Crisis}

As a result of the intensification of ethnic/sectarian conflicts in close/neighboring states and the increase of regional instability, Turkey's need for an air defense system has increased to eliminate the threat elements that may affect it (Seren, 2015, 7). In this context, as a NATO country, Turkey requested the Patriot air defense system from its allies but could not get any results. So much so that in the Syrian civil war, where Turkey needs the air defense system more than ever, it is known that the USA and Germany withdrew their Patriot systems in Turkey for technical reasons. On the other hand, Turkey, which was involved in the US-led F-35 project as both a production partner and a customer in 2002, signed an agreement to buy F-35s from the US and paid $\$ 1.40$ billion, but the US did not give the F-35s to Turkey (CNNTÜRK, 2019). After these developments, Turkey began negotiations with China and Russia to supply an air defense system, and subsequently signed an agreement with Russia for S-400s (Kurt, 2019, 9-11). This agreement, which Turkey signed in 2017 to purchase S-400s from Russia, became an important agenda item in Turkish American relations and caused a crisis.

The United States is uncomfortable with Turkey's purchase of the S-400s for several reasons. The first of these is that the S-400 air defense system is against NATO's interests and cannot be used together with the NATO defense system. Another is that US companies risk losing the Turkish market since F-35 and Patriots will not be sold to Turkey if Turkey buys the S-400s (Yücel, 2020, 9-11). Another reason is concerned that the hidden features of the new generation F-35 produced in the USA may be deciphered by the radars of the S-400 missile defense system (Medeni, 2018, 14). Finally, the United States believes that Turkey can be a precedent for other possible countries considering a close strategic relationship with Russia, and therefore does not consent. Ultimately, the US and NATO are concerned that the increasing relations between Russia and Turkey may undermine the balance of power in the region and change Turkey's priorities (Danforth, 2021, 5). Turkey's point of view on this issue is that technical issues between the S-400 defense system and the F-35 technology can be resolved in short-term flights. While Russia deploys S-400s in Syria, Israel and Britain's operation with F-35s in Syria is an example. In addition, Turkish officials state that the S-400s will be completely 
independent of the NATO system and will be deployed at different points than the F-35s (Habertürk, 2019). On the other hand, Turkey desires to buy both S-400s and F-35s. However, it is thought that the USA is using the F-35 project as a political tool against the S-400s (Kurt, 2019, 11-18).

As a result, Turkey remains committed to the S-400 to take a deterrent step against its risks. On the other hand, the USA announced that Turkey was removed from the F-35 program indefinitely. In addition, the US Congress decided to apply the sanctions foreseen under CAATSA on December 14, 2020. Trump, on the other hand, opposed the idea of US Senators imposing sanctions on Turkey. He accused the Obama administration of treating Turkey unfairly and forcing Erdogan to buy the S-400 air defense system from Russia (Gülmez, 2020, 483). Taylor (2020) claims that Turkey threatened the USA to close the Incirlik base and Kürecik radar station to prevent sanctions taken by the US Congress and to buy the Patriot system. The first action on the issue during the Biden era, which took over the presidential seat from Trump, was the announcement that the sanctions would take effect on April 7, 2021 (Mally, 2021). It is seen that these sanctions are directed against Turkey's defense industry.

\subsection{The East Mediterranean and the Energy Crisis}

While it is thought that the hydrocarbon reserves recently discovered in the Eastern Mediterranean will be the catalyst for peacebuilding in the region, the countries' struggle to gain a share of these resources and the struggle to become a dominant power in the region has revealed an international problem. It is observed that there are also disagreements in the areas of maritime jurisdiction and Exclusive Economic Zone (EEZ), especially among the countries experiencing political problems. When the subject is handled within the framework of international law, article 74 of the United Nations Convention on the Law of Sea (UNCLOS) of 1982 is as follows (1982):

"The delimitation of the exclusive economic zone between States with opposite or adjacent coasts shall be effected by agreement on the basis of international law, as referred to in Article 38 of the Statute of the International Court of Justice, in order to achieve an equitable solution."

In addition, both the geographical characteristics of the Eastern Mediterranean and the fact that some countries in the region identify and cooperate with bilateral or triple EEZs, granting exploration and drilling licenses to international companies and starting these activities make the issue complicated (Ünver-Noi, 2019, 13). Another point that should be mentioned at this point is related to the status of Cyprus. Because the TRNC is not recognized by other states and the only representative of Cyprus is the Greeks, it becomes difficult to resolve disputes. In this context, the fact that Turkey and the United States adopt different policies in the Eastern Mediterranean confronts the two countries and causes another crisis.

For Turkey, the Eastern Mediterranean region is important both for its national security and economy and for its historical ties with the TRNC. The crisis in Syria poses the risk of a terror corridor extending to the Mediterranean in the south of Turkey. On the other hand, Greece's formation of the Eastern Mediterranean Natural Gas Forum, the Greek Cypriot Administration, Israel, Egypt, France, and the USA in the Eastern Mediterranean, carries risks for Turkey's energy security and policies. In addition, protecting the interests of the Turkish Cypriot people is a priority issue for Turkey. In this direction, Turkey has taken some steps. For example, the Greek Cypriot Administration notified Israel and Egypt to the UN on the grounds that they violated their maritime jurisdiction. 
It has signed maritime jurisdiction agreements with the TRNC and Libya. It has continued its oil and natural gas exploration activities with seismic exploration and drilling ships in the regions it accepts within its own continental area (İnat, 2019).

For the USA, the importance of the Eastern Mediterranean can be considered from three different angles. The first is that the Mediterranean is of critical importance for the security of Europe. The second is that the Mediterranean is an important route for the transfer of forces between the Asia Pacific, Persian Gulf, Indian Ocean, and Atlantic regions. The third is to actively participate in the conflicts in the Eastern Mediterranean and North Africa such as Cyprus, Syria, Egypt, Libya, Iraq, and Palestine due to tension with Russia (Tarakçı, 2019, 3-4). In this context, some articles of the draft bill discussed at the US Congress on May 22, 2019, for the development of security and energy partnership in the Eastern Mediterranean give clues about America's perspective towards the region in general and Turkey in particular. In this context, the main goal is to free Europe from its natural gas dependence on Russia. Therefore, it is emphasized that the security of the allies in the Eastern Mediterranean is critical to the security of the United States and Europe, and Greece, Israel and the Greek Cypriot Administration are mentioned as important partners in the region. In articles related to Turkey, it is stated that CAATSA sanctions will be initiated and that if the purchase of the $S-400$ from Russia is abandoned, it may be possible to return to the F-35 program (US Congress, 2019). As a result, the politics of both countries regarding the region diverge.

\section{Determinants of Turkish American Relations and Future Expectations}

When evaluated in general, it is seen that the different threat perceptions between the AKP leadership and the US administrations and the decreasing credibility of the bilateral relationship played an important role in explaining the rising tension in Turkish American relations in the last decade. Mediocre rhetoric and minimal agreement on action led the parties to question bilateral relations and distance themselves from each other. What holds the parties together under these conditions? How is it possible for relationships to turn into an institutional and functional framework? Kupchan's (2010) approach to "stable peace" between sovereign states is guiding in this sense. Achieving a consensus in crises in Turkey-USA relations, in other words, determining the strategies to be followed to bring bilateral relations to a normative level, will be possible by correctly identifying the risks and opportunities. Ultimately, the parameters that will determine behavior in bilateral relations are the importance of the issues in dispute for the parties and the value that the parties give to each other. In addition, as stated at the beginning of the study, according to the constructivism approach, actors associate or change their identities with new norms through socialization, redefine their interests in this direction and act accordingly. In this context, policies can be developed considering the risks that may be encountered in the continuation of the crises in bilateral relations and the opportunities that can be brought about by reconciliation. From this point of view, for Turkey, when the crises experienced are evaluated, the existing risks, opportunities, and possible policies can be shown as in Table 1. 
Table 1: Crisis Analysis (Turkey)

\begin{tabular}{|c|c|c|}
\hline Risks & Opportunities & Possible Policies \\
\hline $\begin{array}{l}>\text { Continuation of terrorist } \\
\text { activities both in Syria and in } \\
\text { the region } \\
>\text { Increasing ethnic separation } \\
\text { in Syria and the possibility of } \\
\text { Syria's partition } \\
>\text { PYD/YPG's acquisition of an } \\
\text { autonomous zone } \\
>\text { Continuation of FETO's } \\
\text { activities in the USA } \\
>\text { The continuation of negative } \\
\text { perception towards Turkey } \\
\text { at official and social level in } \\
\text { the USA } \\
>\text { The USA's continued support } \\
\text { for the countries that have } \\
\text { anti-Turkey policies in the } \\
\text { Eastern Mediterranean. } \\
>\text { Expansion of CAATSA } \\
\text { sanctions } \\
>\text { Possibility of new sanctions } \\
\text { on the grounds that the } \\
\text { embargo on Iran has been } \\
\text { violated }\end{array}$ & $\begin{aligned} & \text { Advantages of Turkey's } \\
& \text { geopolitical location } \\
&> \text { Turkey's model country } \\
& \text { potential } \\
&> \text { Providing energy } \\
& \text { transportation to Europe more } \\
& \text { safely and economically } \\
& \text { through Turkey } \\
&>\text { Turkey's effective role against } \\
& \text { international terrorism } \\
&>\text { Being a significant military } \\
& \text { force as a NATO member and } \\
& \text { keeping bases on its borders } \\
&>\text { Being a crucial actor in tackling } \\
& \text { with the refugee problem } \\
&>\text { The US needs Turkey's support } \\
& \text { in the region in case of } \\
& \text { withdrawal from Syria }\end{aligned}$ & $\begin{array}{l}\text { To increase lobbying } \\
\text { activities before the } \\
\text { members of Congress to } \\
\text { convey Turkey's policies } \\
\text { and security concerns } \\
>\text { Institutionalizing ties } \\
\text { between both civilian and } \\
\text { military foreign policy } \\
\text { bureaucrats } \\
>\text { Running multi-track } \\
\text { diplomatic channels to } \\
\text { build a better } \\
\text { understanding between } \\
\text { the citizens of both } \\
\text { countries } \\
\text { To create stabilizing areas } \\
\text { such as economy, trade, } \\
\text { tourism, cultural and } \\
\text { human interaction }\end{array}$ \\
\hline
\end{tabular}

One issue that needs to be addressed regarding the crises in Turkey-USA relations is the existential differences. Ultimately, the impact of regional developments on bilateral relations makes this issue important. When evaluated in the context of Syria and the Eastern Mediterranean crisis, Turkey is ontologically a part of the region. The USA, on the other hand, penetrates the region with its policies as a non-regional actor. Therefore, in the face of an event taking place in the region, the USA may choose the wait-and-see method or pursue its divide-and-rule policy and its strategic interests through the balance of power between separation and disintegrating elements. In contrast, Turkey may be primarily responsible or affected by a development in the region. At the same time, its strategic interests are based on cooperation-oriented regional integration. This leads to the differentiation of the goals of both countries and the methods to be followed in achieving these goals. For example; The USA sees the region located on the southeast line of Turkey and including Syria as the Kurdish territory with alliance relations and generalizes the military operation Turkey carried out against the region within the scope of security measures as an attack on the innocent Kurdish people (Rand Corporation, 2020). However, it would not be wrong to say that Turkey, as a country in the region, is better able to distinguish those who are Kurds who have no connection with any terrorist act compared to the USA, which is a non-regional actor. As a matter of fact, it is known that Turkey shares its information notes containing its embracing and inclusive policies towards Kurdish citizens in the region with American officials (Acun Keskin, 2017, 39). On the other hand, it has been observed that mutual high-level visits between policy makers of the two countries in the past years have enabled consultations, and negotiations on common issues, facilitating the parties to clearly convey their perceptions, trends, and positions to their interlocutors. In this context, when today's communication channels are considered, ties between civilian and military diplomats should be institutionalized. In addition, the Turkish authorities must raise awareness by sharing their arguments with the US public, the press, civil society, and 
pressure-interest groups to prevent lobbying against them. For example, corruption and irregularities in FETO schools operating in the USA may be brought to the agenda as an issue that may concern every American citizen who pays taxes. As a result, it can be said that some issues that can be solved with public diplomacy and sensitivity have grown and become chronic.

When the crises experienced in terms of the USA are evaluated, the existing risks, opportunities and possible policies can be shown as in Table 2.

Table 2: Crisis Analysis (USA)

\begin{tabular}{|c|c|c|}
\hline Risks & Opportunities & Possible Policies \\
\hline $\begin{array}{l}\text { Losing an important ally like } \\
\text { Turkey } \\
\text { Turkey's expansion of } \\
\text { cooperation with Russia, } \\
\text { Iran, and China } \\
\text { Military and economic costs } \\
\text { that will be faced in the } \\
\text { continuation of the state of } \\
\text { instability in Syria } \\
\text { Increasing negative } \\
\text { perception towards USA in } \\
\text { Turkey } \\
\text { Instability in Syria harms the } \\
\text { American fight against } \\
\text { terrorism on a global scale }\end{array}$ & $\begin{array}{l}\text { To play an active role as a } \\
\text { global power in the solution of } \\
\text { the Syrian crisis } \\
>\text { To gain the trust of both } \\
\text { Turkey and other allies by } \\
\text { solving the problems with } \\
\text { Turkey } \\
>\text { Acting jointly against terrorism } \\
>\text { Taking advantage of the } \\
\text { Turkish market in commercial } \\
\text { activities } \\
>\text { To reduce the energy } \\
\text { dependence of Europe on } \\
\text { Russia by cooperating with } \\
\text { Turkey } \\
>\text { Taking advantage of Turkey's } \\
\text { balancing role in policies } \\
\text { towards Iran and Russia }\end{array}$ & $\begin{array}{l}\text { Ending support for } \\
\text { PYD/YPG and FETO } \\
>\text { Reclaiming the heavy } \\
\text { weapons given to the } \\
\text { PYD/YPG } \\
>\text { To support Turkey's safe } \\
\text { zone plan } \\
>\text { To establish a joint } \\
\text { working group with } \\
\text { Turkey on the integration } \\
\text { of air defense systems } \\
>\text { To coordinate the } \\
\text { development and fair } \\
\text { distribution of } \\
\text { hydrocarbon resources in } \\
\text { the Eastern Mediterranean } \\
\text { between the countries of } \\
\text { the region }\end{array}$ \\
\hline
\end{tabular}

From the point of view of the United States, if the positive course of bilateral relations and the long-term value of relations are important, it can be assumed that Turkey will be more inclined to understand its position and demands and show flexibility. Because implementing policies that consider Turkey's security concerns will also eliminate the risks that may be encountered in case of failure to reach consensus in bilateral relations.

\section{Conclusion}

In this study, it is argued that the reconstruction of the state identity of any secondary power in a unipolar international system changes its foreign policy vision, threat perceptions and international goals, leading to crises in the system's relations with the superpower. To test this argument, Turkish-American relations were examined and verified. In today's Turkish American relations, there are significant disagreements on Syria and the PYD/YPG, the July 15 coup attempt and FETO, the S-400 Air Defense System, and the Eastern Mediterranean, and these have turned into a crisis. The shocks in the dominant power paradigm of the USA, which leads the international system with its power and prestige, brought some consequences. One of them is the emergence of alternative power centers such as China, Russia, and Germany. Another is the instability created by the power vacuum in the international system, as observed, particularly in the Middle East. Another consequence is that the US loses its allies.

The USA wanted to continue its relations with Turkey within the framework of an asymmetrical structure, as it was during the Cold War. However, the US ignoring Turkey's interests and priorities while achieving its global-macro goals caused a problem of trust. As a result, Turkey acted with the motive of being a state with higher 
autonomy in international politics and wanted to establish a balanced relationship of interdependence with the United States, protecting the interests of both sides. The conflict between the policies pursued by the two countries caused crises. At this point, it can be said that the main reason for all these conflicts and crises is related to the structure of the international system and having different expectations in bilateral relations. In addition, it is seen that the interests that shape foreign policy are built based on identity.

In the historical development of Turkey-US relations, the United States has sometimes been a reliable port for Turkey and sometimes a partner avoiding support even when needed. A similar situation has been seen on the US side, and Turkey has been interpreted as both a strategic alliance or model partner and a difficult ally. It is certain that the relations between Turkey and the USA have become tense, especially in the recent period, with the crises arising from policy and strategy differences. As a matter of fact, this situation is closely related to how the parties define their own identity and interests. However, the parties' escalating the crisis and breaking down the bridges cannot be regarded as a reasonable concept or a rational idea. Ultimately, relations between states are based on mutual interests rather than unilateral dependence. Because both countries benefit from each other's opportunities mutually. The preservation, strengthening and maintenance of this relationship are only possible if the two states meet at minimum commons in the definition of threats and interests shaped by their own identities, cultures, and norms. Considering that identities can be built socially, determining policies by evaluating the crises in Turkish American relations regarding risks and opportunities will be the cornerstone of getting rid of the tense atmosphere. 


\section{References}

Acun, Can, - Keskin, Bünyamin. The PKK's Branch in Northern Syria PYD - YPG. Ankara: SETA, 2017.

Akbaş, Zafer vd. "İkinci Yüzyılında İşbirliği ve Çatışma Sarmalında Türk- Amerikan İlişkileri”. International Journal of Society Researches 13/19 (2019), 2226-2258.

Akgün, Mert Hüseyin. "Türkiye-ABD Suçluların Geri Verilmesi Anlaşması ve FETÖ Liderinin İadesi”. Seta Perspektif 150 (2016), 1-6.

Aktan, İrfan. "Soli Özel: Rahip Brunson gerilimin sebebi değil, simgesi". (2018, August 13). https://www.gazeteduvar.com.tr/yazarlar/2018/08/13/soli-ozel-rahipbrunson-gerilimin-sebebi-degil-simgesi

Altunışık, Meliha Benli. "Worldviews and Turkish foreign policy in the Middle East". New Perspectives on Turkey 40/1 (2009), 169-192.

Athanassopoulou, Ekavi. "American-Turkish relations since the end of the Cold War". Middle East Policy 8/3 (2001), 144-164.

Atılgan, Ayşe Hümeyra. “Obama deceived Turkey over PKK, Erdogan says”. (2017, April 20). https://www.aa.com.tr/en/turkey/obama-deceived-turkey-over-pkkerdogan-says/801043

Bal, İdris. "Türkiye-ABD İlişkileri ve 2003 Irak Savașı'nın Önemi”. 21. Yüzyılda Türk Dış Politikası. ed. İdris Bal, 151-184, Ankara: Global Research Center, 2006.

Barkey, Henri. "Syria's Dark Shadow over US-Turkey Relations”. (2016, March 7). http://turkishpolicy.com/article/782/syrias-dark-shadow-over-us-turkeyrelations

Çağaptay, Soner. “Trump's letter to Turkey's Erdogan shows the US. Is struggling to keep up with Ankara". Nbc News (2019, October 17). https://www.nbcnews.com/think/opinion/turkey-s-erdogan-plays-trump-putinhe-tries-remake-middle-ncna 1067736

Çalış, Şaban. "Dış Politikada Eksen Kaymıyor, İstikamet Düzeliyor". Mülakatlarla Türk Dış Politikası II. ed. Habibe Özdal vd. 65-102, Ankara: USAK, 2010.

CNNTÜRK. “Cumhurbaşkanı Erdoğan'dan F-35 açıklaması”. (2019, September 26). https://www.cnnturk.com/dunya/cumhurbaskani-erdogandan-f-35-aciklamasi

Danforth, Nicholas. "Between Cooperation and Containment: New US Policies for a new Turkey". Brookings (2021, February). https://www.brookings.edu/research/between-cooperation-and-containmentnew-us-policies-for-a-new-turkey/

Deutsche Welle. "Trump, Erdogan lavish praise despite deep divisions in US Turkey ties". (2019, Nowember 11). https://www.dw.com/en/trump-erdogan-lavish-praisedespite-deep-divisions-in-us-turkey-ties/a-51233267

Erdağ, Ramazan. "Normalleşmeden gerilim ve çatışmaya: Türkiye-Suriye ilişkileri". $A K$ Parti’nin 15 Yllı. ed. Kemal İnat vd. 318-335, İstanbul: SETA, 2017.

Erhan, Çağrı - Sıvış, Efe. "Determinants of Turkish-American relations and prospects for the future". Winter 19/1 (2017), 89-115.

Euronews. "Batılı istihbarat örgütlerinin 15 Temmuz raporları". (2017, July 13). 
https://tr.euronews.com/2017/07/13/batili-istihbarat-orgutlerinin-15temmuz-raporlari

Flockhart, Trine. "Complex Socialization: A Framework for the Study of State Socialization”. European Journal of International Relations 12/1 (2006), 89-118.

Gülmez, Didem Buhari. "The resilience of the US-Turkey alliance: divergent threat perceptions and worldviews". Contemporary Politics 26/4 (2020), 475-496.

Habertürk. "Bakan Hulusi Akar'dan S-400 ve F-35 açıklaması". (2019, April 16). https://www.haberturk.com/son-dakika-bakan-hulusi-akar-dan-s-400-ve-f-35aciklamasi-2433991

Hale, William. Turkish foreign policy since 1774. London and New York: Routledge, 2013.

İnat, Kemal. “Doğu Akdeniz Sorununun Nedenleri ve Türkiye'nin Politikası”. (2019, December 11). https://www.setav.org/dogu-akdeniz-sorununun-nedenleri-veturkiyenin-politikasi/

Kalın, İbrahim. "After the Coup Attempt, Turkey's Success Story Continues". Insight Turkey 18/3 (2016), 11-17.

Kanat, Kılıç Buğra. "2014 Yılında Türk-Amerikan İlişkileri: Taktiksel Farklılıklardan Stratejik Muammaya". Türk Dış Politikası Yıllı̆̆ı 2014. ed. Burhanettin Duran vd. 331-354, Ankara: SETA, 2015.

Kanat, Kılıç Buğra. “Türkiye'nin ABD Politikası 2016”. Türk Dış Politikası Yıllığı 2016. ed. Burhanettin Duran vd. 319-340, Ankara: SETA, 2017.

Kanat, Kılıç Buğra. “Türkiye'nin ABD Politikası”. Türk Dış Politikası Yıllığı 2017. ed. Burhanettin Duran vd. 287-308, Ankara: SETA, 2018.

Kanat, Kılıç Buğra vd. Türkiye-ABD ilişkileri ve yeni ABD yönetimi. Ankara: SETA, 2017.

Kösebalaban, Hasan. Turkish Foreign Policy: Islam, Nationalism, and Globalization, London: Palgrave Macmillan, 2014.

Kupchan, Charles. How Enemies Become Friends: The Sources of Stable Peace, Princeton-Oxford: Princeton University Press, 2010.

Kurt, Veysel. S-400 \& F-35 Denklemi. İstanbul: SETA Analiz, 2019.

Langan, Mark. "Virtuous power Turkey in sub-Saharan Africa: The 'Neo-Ottoman' challenge to the European Union". Third World Quarterly 38/6 (2017), 13391414.

Lévy, Bernard Henri. "NATO Should Give Turkey the Boot". (2018, August 13). https://www.wsj.com/articles/nato-should-give-turkey-the-boot-1534201627

Mally, Alec. "US sanctions for Turkey's S-400 procurement come into effect”. (2021, April 8). https://www.neweurope.eu/article/us-sanctions-for-turkeys-s-400procurement-come-into-effect/

Mason, Jeff - Landay, Jonathan. “Obama urges rule of law in Turkey, US warns of damage to relations”. (2016, July 16). https://www.reuters.com/article/us-turkeysecurity-obama-idUSKCNOZWORJ

Medeni, Muhammed Hadi. Türkiye-ABD İlişsilerinde Yaşanan Krizler ve Türk Siyasi Elitinin Yeni Strateji Arayışları. Baghdad: Al-Beyan Research and Planning Center, 
2018.

Miş, Nebi vd. 15 Temmuz Darbe Girişimi Toplumsal Algı Araştırması. Ankara: SETA, 2016.

Nissenbaum, Dion - Lee, Carol. "Turkish President Faces a Cool Reception in US Visit". (2016, March 27). https://www.wsj.com/articles/turkish-president-faces-a-coolreception-in-u-s-visit-1459114068

Oktay, Mücahit. “ABD’de kabul görmek ve illegal faaliyetlerini perdelemek isteyen FETÖ, tüm lobi araçlarını kullanıyor”. (2021, April 13). https://www.aa.com.tr/tr/dunya/abdde-kabul-gormek-ve-illegal-faaliyetleriniperdelemek-isteyen-feto-tum-lobi-araclarini-kullaniyor/2207263

Oran, Baskın. Turkish Foreign Policy: 1919-2006. Salt Lake: University of Utah Press, 2011.

Örmeci, Ozan. "Typology of Crises in Turkish-American Relations: A Study of Eight Cases", UPA Strategic Affairs 1/1 (2020a), 32-50.

Örmeci, Ozan. "Turkish-American Relations in the Post-Cold War Era". Historical Examinations and Current Issues in Turkish-American Relations 61-115, Bern: Peter Lang, 2020b.

Paletta, Damian. "Pentagon Allies Jailed in Turkey Amid Coup Backlash, General Says". (2016, July 28). https://www.wsj.com/articles/BL-WB-64728

Peters, Ralph. "Turkey's last hope dies". (2016, July 16). https://www.foxnews.com/opinion/turkeys-last-hope-dies

Pipes, Daniel. "Does Turkey Still Belong in NAT0?". (2009, April 6). http://www.danielpipes.org/6269/does-turkey-still-belong-in-nato

Rand Corporation. Turkey's Nationalist Course, California, 2020.

Reuters. "Erdogan Says US-Led Coalition Gives Support to Terrorist Groups in Syria". (2016, December 27). https://www.reuters.com/article/us-mideast-crisis-syriaturkey-idUSKBN14G1EU

Reuters. "US Will Take Weapons from Kurds after Islamic State Defeat: Turkey". (2017, June 22). https://www.reuters.com/article/us-mideast-crisis-syria-turkey-usaidUSKBN19D10J

Reuters. 'Trump threatens to 'obliterate' Turkey's economy if it takes 'off-limits' actions". (2019a, October 7). https://www.reuters.com/article/us-syria-securityturkey-usa-economy/trump-threatens-to-obliterate-turkeys-economy-if-it-takesoff-limits-actions-idUSKBN1WM1R3

Reuters. "Turkey to oppose NATO plan if it fails to recognize terrorism threats: Erdoğan”. (2019b, December 3). https://www.reuters.com/article/us-natosummit-syria-erdogan/turkey-to-oppose-nato-plan-if-it-fails-to-recognizeterrorism-threats-erdogan-idUSKBN1Y70KT

Rhee, Starr. "The Future of US-Turkey Relations", Boston: Harvard Model Congress, 2020.

Rosenau, James. The Scientific Study of Foreign Policy, New York: The Free Press, 1971.

Rubin, Mivhael. "Michael Rubin: Turkey in NATO? No! ". (2016, April 29). http://www.tulsaworld.com/opinion/othervoices/michaelrubin-\%0Aturkey-in- 
nato-no/article_63e893ad-d5ec-5e64-aad0-d190f240166c.html.\%0A

Şahin, Güngör. "Uluslararası ilişkiler teorileri kapsamında Amerika Birleşik Devletleri dış politikası ve güvenlik stratejisi”. Elektronik Siyaset Bilimi Araştırmaları Dergisi 10/2 (2019), 62-79.

Seren, Merve. "Türkiye'nin Füze Savunma Sistemi”, İstanbul: SETA, 2015.

Sloat, Amanda. "How to Save the U.S.-Turkey Relationship". (2018, July 30). https://www.foreignaffairs.com/articles/europe/2018-07-30/how-save-usturkey-relationship

Sönmezoğlu, Faruk. II. Dünya Savaşı'ndan Günümüze Türk Dış Politikası, İstanbul: Der Yayınları, 2006.

Sözcü. “ABD 'Türkiye IŞ่iD’le mücadele etmiyor' diyor ama....”. (2018, January 27). https://www.sozcu.com.tr/2018/dunya/abd-turkiye-isidle-mucadele-etmiyordiyor-ama-2190333/

Sözen, Ahmet. "A paradigm shift in Turkish foreign policy: Transition and challenges", Turkish Studies 11/1 (2010), 103-123.

Stanicek, Branislav. “Turkey's military operation in Syria and its impact on relations with the EU", Brussels: European Parliament, 2019.

Tarakçı, Nejat. “Güç Dengeleri Işığında Türkiye'nin Doğu Akdeniz Stratejisi Nasıl Olmalıdır?”. Ankara: TASAM, 2019.

Taylor, Paul. "How rogue can Turkey go?". (2020, January 1). https://www.politico.eu/article/turkey-rogue-state-recep-tayyip-erdogan/

Temizer, Selen. “Dışişleri Bakanı Çavuşoğlu: Umarım ABD’nin tüm kurumları PYD ile ilgili gerçekleri anlar". (2016, February 22). https://www.aa.com.tr/tr/turkiye/disisleri-bakani-cavusoglu-umarim-abdnintum-kurumlari-pyd-ile-ilgili-gercekleri-anlar/525240

The Economist. "After the Coup, Turkey Turns against America". (2016, July 18). https://www.economist.com/europe/2016/07/18/after-the-coup-turkey-turnsagainst-america.

Timoçin, Dilge. “Cook: ABD’nin YPG’yle Çalışma Kararını Türkiye Verdi”. (2017, May 27). https://www.amerikaninsesi.com/a/cook-abd-nin-ypg-yle-calisma-kararini-birsekilde-turkiye-vermis-oldu/3873540.html

Todayonline. "US urges Turkey to remain focused on Islamic State, not attack Syria's Afrin". (2018, January 18). https://www.todayonline.com/world/us-urgesturkey-remain-focused-islamic-state-not-attack-syrias-afrin.

Turaman, Okan - Çelik, Ahmet Hüsrev. “Türkiye ve ABD’nin Ortadoğu Dış Politikası: Irak ve Suriye Örnekleri Üzerinden Çatışan ve Örtüşen Değerler İkilemi”. Düzce Üniversitesi Sosyal Bilimler Enstitüsü Dergisi 8/1 (2018), 116-138.

Ünver-Noi, Aylin. “Doğu Akdeniz'de ABD, AB ve Türkiye İlişkileri Nereye?”, Europolitika, (2019), 13-16.

UN Convention on the Law of the Sea. https://www.un.org/Depts/los/convention_agreements/ texts/unclos/unclos_e.pdf , 1982. 
US Congress. "Eastern Mediterranean Security and Energy Partnership Act of 2019. (2019, June 25). https://www.congress.gov/bill/116th-congress/senatebill/1102/text

Uslu, Nasuh. Türk Amerikan İlişkileri. Ankara: 21. Yüzyıl Yayınları, 2000.

US National Security Strategy. (2002, September). https://20092017.state.gov/documents/organization/63562.pdf

US National Security Strategy. (2015, February). https://obamawhitehouse.archives.gov/sites/default/files/docs/2015_national_ security_strategy_2.pdf

Uzgel, İlhan. “ABD ve NATO’yla İlişkiler”, Türk Dış Politikası Kurtuluş Savaşı'ndan Bugüne Olgular, Belgeler, Yorumlar Cilt II: 1980-2001. ed. Baskın Oran, 243-325, İstanbul: İletişim Yayınları, 2010.

Wendt, Alexander. "Anarchy is What States Make of It: The Social Construction of Power Politics”. International Organization 46/2 (1992), 391-425.

Wendt, Alexander. Social Theory of International Politics. Cambridge: Cambridge University Press, 1999.

Williams, Audrey - Snow, Alexander. "Major Developments in U.S.-Turkey Relations Following the July 15 Coup Attempt". (2017, July 13). https://www.turkheritage.org/en/publications/factsheets/security/majordevelopments-in-us-turkey-relations-following-the-july-15-coup-attempt-4566

Yeșiltaş, Murat vd. “Sınırdaki Düşman: Türkiye’nin DAİŞ ile Mücadelesi”. İstanbul: SETA, 2016.

Yücel, Hasan. “Türk-Amerikan İlişkilerinde S-400 Krizi”, İstanbul: SETA, 2020.

Zehfuss, Maja. “Constructivism and Identity: A Dangerous Liaison”, European Journal of International Relations 7/3 (2001), 315-348. 